\title{
PHYTOCHEMICAL AND ANTIOXIDANT SCREENING OF AMOMUM SUBULATUM, ELETTARIA CARDAMOMUM, EMBLICA OFFICINALIS, ROSA DAMASCENE, SANTALUM ALBUM AND VALERIANA OFFICINALIS AND THEIR EFFECT ON STOMACH, LIVER AND HEART
}

\author{
Sadia Mehvish*, Muhammad Qasim Barkat \\ Institute of Pharmacy, Physiology and Pharmacology, University of Agriculture, Faisalabad, Pakistan \\ *Corresponding Author Email: sadia-mehvish@hotmail.com
}

This is an open access article distributed under the Creative Commons Attribution License, which permits unrestricted use, distribution, and reproduction in any medium, provided the original work is properly cited.

\section{ARTICLE DETAILS}

\section{Article History:}

Received 26 June 2018 Accepted 2 July 2018

Available online 1 August 2018

\begin{abstract}
Plants and herbs are the mainstream of diverse traditional medicine system practiced throughout the whole population. Today, there is increasingly trend set the uses of natural plants for the various human ailments and wound healing as natural remedy. The crude drugs are derived from the whole plant or parts of the plants that are being used for tremendous diseases through the world without chances of serious adverse reaction as well as more efficacy and safety. The ethnomedicines are being indicated worldwide that consists of different phytochemical constitutes like as alkaloids, saponin, phenols, tannins, flavonoids and carbohydrates so as to not only have biological, physiological and pharmacological activity but also have antioxidant activity for the treatment of stomach, cardiovascular and liver alilments.
\end{abstract}

\section{KEYWORDS}

Traditional medicine, ethnomedicines, pharmacological, cardiovascular.

\section{INTRODUCTION}

Herbs and plants are the base of various traditional medication systems practiced all over the world. Whole plant or different parts of plants particularly the roots are major sources that directly provide crude drugs. A variety of conventional medication systems being used worldwide includes Indian medicinal system (consisted of two foremost branches, Unani and Ayurveda), ancient Chinese medicinal system and Amazonian ethnomedicine. These prescribing trends are based upon the use of herbal plants for treatment of ailments and healing. Unani madicines are being used by human for treatment of ailments from the time of ancient Greece [1]. Human beings have been used medicinal plants in curing various disorders and ailments because these plants seem to be less toxic and also have no significant side effects. Usage of natural plants or any part of plants and particularly certain herbs in the remedy of specific disorders or conditions is come under the category of ethnomedicines [2]. Phytochemicals are present in plants which are secondary metabolites such as phenols, alkaloids, steroids, flavonoids, glycosides, flavonoids, saponins, anthocyanins, cumarins and certain pigments [3]. Reactive oxygen species (ROS) are very reactive molecules due to existence of unpaired electron in their outermost shell. Reactive oxygen species (ROS) are generated in the living organism as a byproducts of regular cellular metabolic reactions. Physiologically reactive oxygen species (ROS) are produced in each cell at low concentration but if they are created at high concentration they can interact with essential cellular targets, including proteins, lipids and DNA, compromising cell viability and functions [4]. In this review paper the Amomum subulatum, Elettaria cardamomum, Emblica officinalis, Rosa damascene, Santalum album and Valeriana officinalis are to be reviewed for stomach, heart and liver ailment due to presence of bioactive compounds and also for investigation of phytochemical screening and ROS status. perennial herb which is indigenous to Himalayan region of India particularly Sikkim. Its common names are Badi Ilayachi or Large cardamom, Nepal cardamom and fruit of this plant being widely used all over the world as spice. Since $6^{\text {th }}$ century Amomum subulatum was utilized in Ayurvedic medicines due to its astringent, stimulant, analgesic, hypolipidaemic, antioxidant, antiulcer, cardioprotective and antimicrobial potentials [5]. Large cardamomum has been used as antihyperglycaemic, carminative, antiulcerogenic, antitussive, antibecterail and cardioprotective agent, to mitigate headache, bad breath, asthma, cough, liver diseases and anorexia [6]. A group researchers have stated that methanolic extract of Amomum subulatum have exhibited significant lipid lowering and antioxidant activities in rabbits [7]. It lowers the total low density lipoproteins (LDL), triglyceride, phospholipid, cholesterol and lipid peroxidation while increases the high density lipoproteins (HDL) level of blood thus can be used as antihyperlipidemic agent [8]. Amomum subulatum have been reported as phytochemical qualitatively (Table 1), quantitatively (Table 2) and Ros (Table 3).

\subsection{Elettaria cardamomum}

Elettaria cardamomum has taken its place in the family Zingiberaceae. It is a persistent plant and its seeds are used as rich spice. Elettaria cardamomum is a herb native to Pakistan, India and Sri Lanka. It's commonly named as "Elaichi", Queen of spices and Small cardamom. Cardamom usually found in two key types "true or Green cardamom" that is Elettaria cardamomum and "Brown or Black cardamom" that is Amomum subulatum.

\section{REVIEW OF LITERATURE}

\subsection{Amomum subulatum}


Table 1: Qualitative phytochemical screening of plants

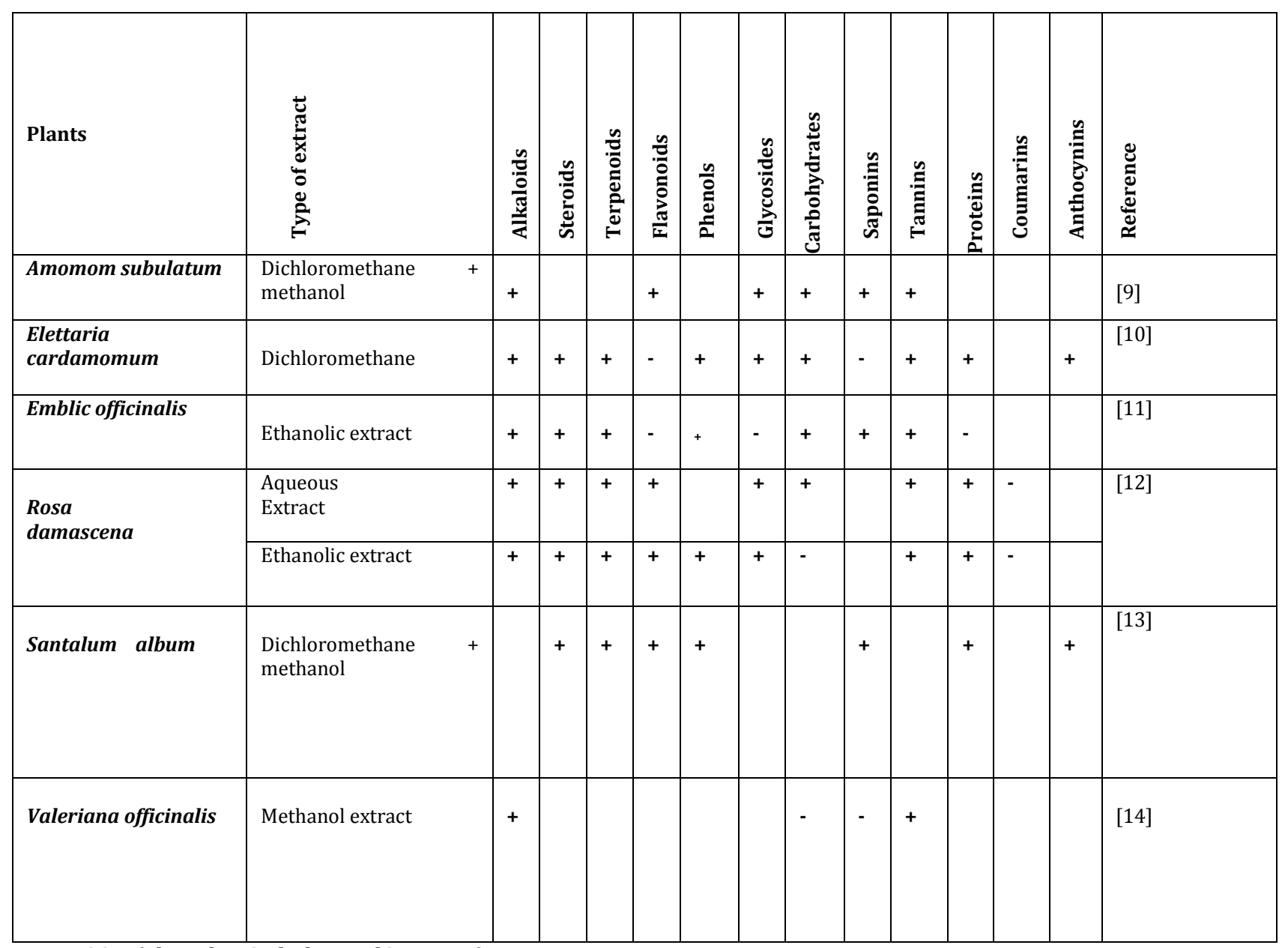

+ve: Positive (Phytochemicals detected in extract)

-ve: Negative (Phytochemicals not detected in extract)

Table 2: Quantitative phytochemical analysis of plants

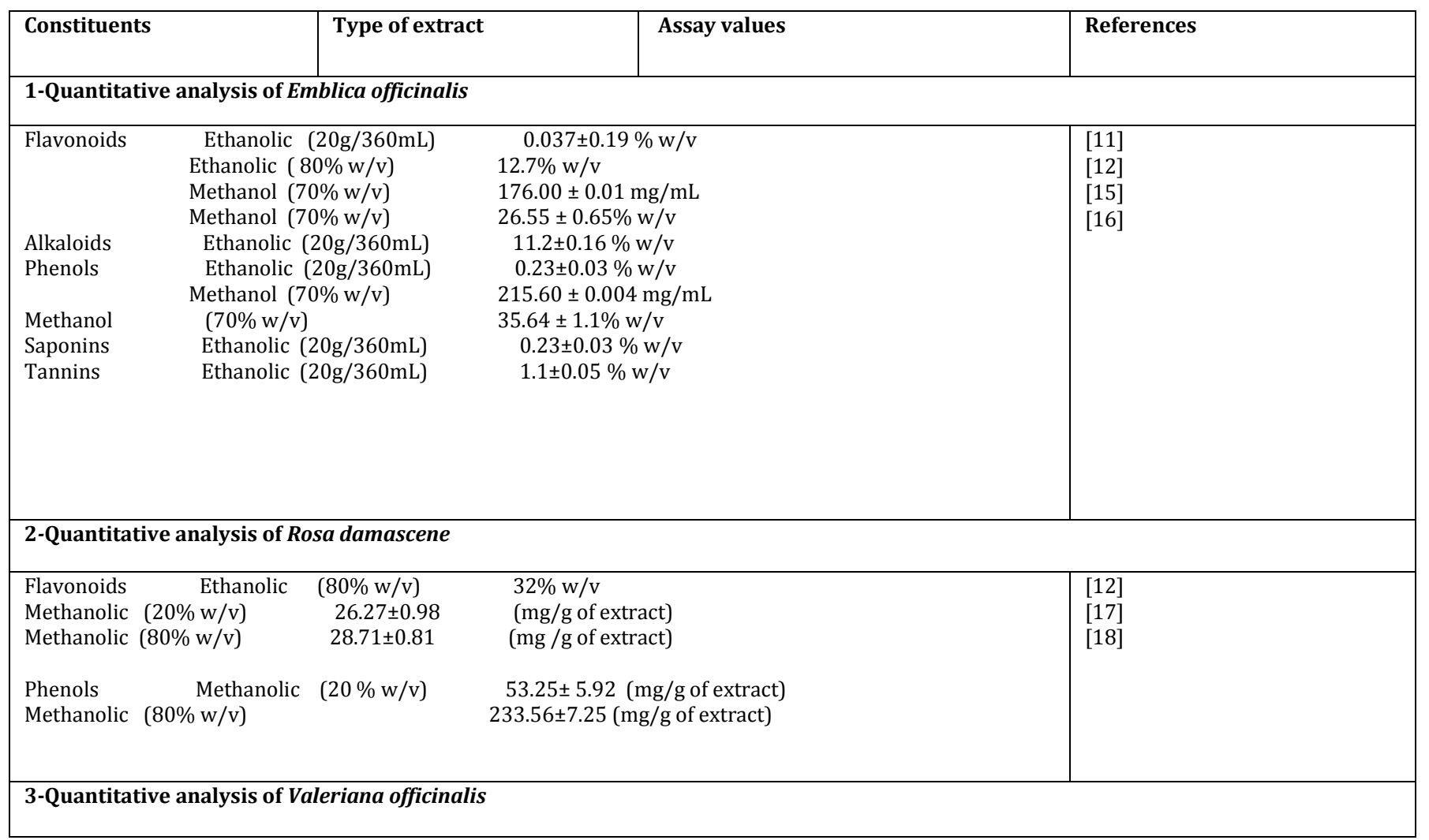




\begin{tabular}{|c|c|c|c|}
\hline Alkaloids & $\begin{array}{l}\text { anolic }(50 \% \mathrm{w} / \mathrm{v}) \\
\text { nolic }(50 \% \mathrm{w} / \mathrm{v})\end{array}$ & $\begin{array}{l}0.01-0.05 \% \mathrm{w} / \mathrm{v} \\
0.5 \%-2.0 \% \mathrm{w} / \mathrm{v}\end{array}$ & $\begin{array}{l}{[19]} \\
{[20]}\end{array}$ \\
\hline \multicolumn{4}{|c|}{ 4-Quantitative analysis of Santalum album } \\
\hline $\begin{array}{lr}\text { Phenols } & \mathrm{Me} \\
\text { Saponins } & \mathrm{Me} \\
\text { Anthocyanins } & \mathrm{M} \\
\text { Terpenoids } & \mathrm{M}\end{array}$ & $\begin{array}{l}\text { thanolic }(80 \% \mathrm{w} / \mathrm{v}) \\
\text { thanolic }(80 \% \mathrm{w} / \mathrm{v}) \\
\text { ethanolic }(80 \% \mathrm{w} / \mathrm{v}) \\
\text { ethanolic }(80 \% \mathrm{w} / \mathrm{v})\end{array}$ & $\begin{array}{l}18-190 \mathrm{mg} \mathrm{g}-^{-1} \\
9.4-43.6 \mathrm{mg} \mathrm{g}_{-} \\
0.01-0.31 \mathrm{mg} \mathrm{g}^{1} \\
17.3-51.4 \mathrm{mg} \mathrm{g}^{-1}\end{array}$ & [13] \\
\hline \multicolumn{4}{|c|}{ 5-Quantitative analysis of Amomum subulatum } \\
\hline $\begin{array}{ll}\text { Phenols } & \mathrm{M} \\
\text { Flavonoids } & \mathrm{M}\end{array}$ & $\begin{array}{l}\text { ethanolic }(50 \% \mathrm{w} / \mathrm{v}) \\
\text { ethanolic }(50 \% \mathrm{w} / \mathrm{v})\end{array}$ & $\begin{array}{l}0.00366 \% \mathrm{w} / \mathrm{w} \\
0.0361 \% \mathrm{w} / \mathrm{w}\end{array}$ & [5] \\
\hline \multicolumn{3}{|c|}{ 6-Quantitative analysis of Elettaria cardamomum } & \\
\hline $\begin{array}{l}\text { Flavonoids contents } \\
\text { Phenolic contents } \\
\text { Phenolic contents }\end{array}$ & $\begin{array}{l}\text { Methanolic }(100 \% \mathrm{w} / \mathrm{v}) \\
\text { Methanolic }(100 \% \mathrm{w} / \mathrm{v}) \\
\text { Ethanolic }(85 \% \mathrm{w} / \mathrm{v})\end{array}$ & $\begin{array}{l}3.59 \mathrm{mg} / \mathrm{g} \text { dry extract } \\
15.67 \mathrm{mg} / \mathrm{g} \text { dry extract } \\
84.19 \pm 4.64 \mathrm{mg} / 100 \mathrm{~g} \text { dry extract }\end{array}$ & $\begin{array}{l}{[21]} \\
{[22]}\end{array}$ \\
\hline
\end{tabular}

Table 3: Antioxidant analysis of the plants

\begin{tabular}{|c|c|c|c|c|c|c|}
\hline Plants & 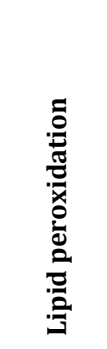 & 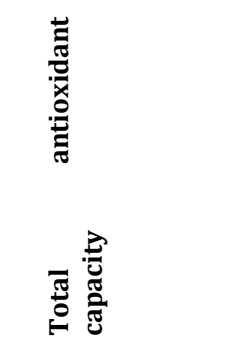 & 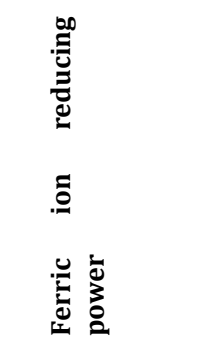 & 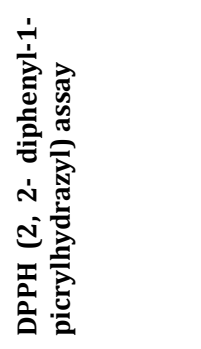 & 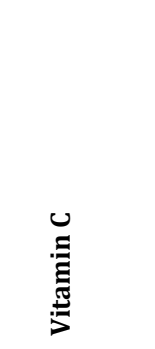 & 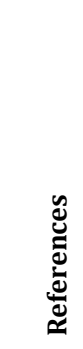 \\
\hline Amomum subulatum & NR & NR & NR & $\begin{array}{l}8.25 \pm 2.0 \\
\mu \mathrm{g} / \mathrm{mL}\end{array}$ & NR & [6] \\
\hline Elettaria cardamomum & NR & NR & $\begin{array}{l}42.4 \% \\
w / v\end{array}$ & $\begin{array}{l}11 \% \\
w / v\end{array}$ & NR & [21] \\
\hline Emblica officinalis & NR & $\begin{array}{l}4.10 \pm 0.17 \\
\text { mmol trolox } \\
\text { equivalent/L }\end{array}$ & NR & $\begin{array}{l}1.43 \pm 0.03 \\
\mu \mathrm{g} / \mathrm{mL}\end{array}$ & $\begin{array}{l}478.56 \\
\mathrm{mg} / 100 \mathrm{~mL}\end{array}$ & $\begin{array}{l}{[23]} \\
{[15]}\end{array}$ \\
\hline Rosa damascena & NR & NR & NR & $\begin{array}{l}77.02 \% \\
\mathrm{w} / \mathrm{v}\end{array}$ & NR & [18] \\
\hline Santalum album & $\begin{array}{l}1.17 \pm 2 \\
\mu \mathrm{g} / \mathrm{mL}\end{array}$ & $61.2 \pm 5 \mu \mathrm{mol} / \mathrm{g}$ & $\begin{array}{l}025.5 \pm 43.5 \\
\mu \mathrm{g} / \mathrm{mL}\end{array}$ & $\begin{array}{l}1.17 \pm 0.2 \mu \mathrm{g} / \\
\mathrm{mL}\end{array}$ & NR & [13] \\
\hline Valeriana officinalis & NR & NR & $\begin{array}{l}235.44 \pm 5.18 \\
\mu \mathrm{g} / \mathrm{mL}\end{array}$ & $\begin{array}{ll}493.4 & \pm \\
4.9 \mu \mathrm{g} / \mathrm{mL}\end{array}$ & NR & [24] \\
\hline
\end{tabular}

NR: Not Reported in Literature

Seeds of Elattria cardamomum contain high percentage of volatile oil that is principally comprised of flavonoids and phenolic constituents. Other constituents of volatile oil of Elettaria cardamomum are proteins, starch, sterols and waxes [25]. By way of in vivo and in vitro methods it was demonstrated that the cardamom extract is effective in the treatment of diarrhea, constipation, colic distress and hypertension. Its crude extract also acts as diuretic, blood pressure lowering and sedative thus enabling this herb to be used in mitigation of epilepsy and 
hypertension [26]. Elettaria cardamomum is used as analgesic antispasmodic, anti-inflamatory, antioxidant, antimicrobial anticonvulsant and sedative. Its volatile oil presented insecticidal activity for stored grain products, protective role in skin disorders, inhibitory effects on platelets aggregation and promising role in smoking cessation [25]. Elettaria cardamomum have been investigated as phytochemical qualitatively (Table 1), quantitatively (Table 2) and ROS (Table 3).

\subsection{Emblica officinalis}

Khan, have described that Emblica officinalis is enlisted as a fundamental plant in Indian indigenous scheme of medication. It belongs to family Euphorbiaceae [27]. It is generally named as Amla, Indian gooseberry or Phyllanthus Emblica. The species are native to India and also grow up in tropical and subtropical regions of Pakistan Srilanka, Uzbekistan, South East, China, Asia and Malaysia. In Ayurveda system, fruits of Emblica officinalis are extensively utilized and assumed to augment resistance against ailments. Dnyaneshwar stated that Emblica officinalis has valuable functions in treatment of cancer, liver, diabetes, ulcer, anemia, heart trouble and a variety of other ailments [28]. Correspondingly, Emblica officinalis is valuable as antipyretic, cytoprotective, antioxidant, gastroprotective, analgesic, immunomodulatory and antitussive agent. Besides these effects, Indian gooseberry was functional in memory enhancing, reducing cholesterol level, ophthalmic disorders, defusing snake venom and antimicrobial agent. Jain and Khurdiya, 2004 had found that its fruit juice was comprised of maximum concentration of vitamin $\mathrm{C}$ that was $478.56 \mathrm{mg} / 100 \mathrm{~mL}$ of the extract [23]. When its fruit was blended with other fruits for example Pusa Navrang grape juice, its level of vitamin C contents was enhanced.

Vijayalakshmi had evidenced that Emblica officinalis have presented significant broad spectrum antibacterial activity against Escherichia coli, Staphylococcus aureus, Salmonella typhi and Bacillusspecies [29]. While no activity against fungi was demostrated. Mayachiew and Devahastin, had determined the antioxidant activity of ethanolic fruit extract of Emblica officinalis on the basis of coupled oxidation of linoleic acid and beta-carotene and it was noticed to be $86.4 \%$ [30]. Goel and Bhattacharya, had accounted the effects of methanolic extract of Emblica officinalis on offensive factors of ulcer like acid-pepsin secretion and defensive factors like cellular mucus, mucin secretion, cell proliferation and cell shedding in order to determine the antiulcerogenic activity of plant [31]. Ulcers are principally caused by disproportion between defensive and offensive factors. Sairam had stated that the methanolic extract of Emblica officinalis exhibited antiulcerative activity via minimizing offensive factors and by promoting defensive mucosal factors [32]. Fruit pulp of Emblica officinalis contained hydrolysable tannins, saponins and Emblicanin A\&B which were accountable for gastro protective effects of Amlain ulcer [33]. Aguwa and Nwako found that tannins had astringent and vasocostrictive outcomes that lead to precipitation of proteins on the site of ulcerative lesions, formation of an impermeable protective layer over the lining and exertion of cytoprotective effect of Amla [34].

Perianayagam have demonstrated that methanolic extract of fruits of Emblica officinalis reduces gastrointestinal motility and PGE2mediated accumulation of intestinal fluid (enteropooling) which can be related to the presence of tannins in Emblica officinalis extract [35]. Long term administration of Emblica officinalis facilitated myocardial adjustment by boosting endogenous antioxidants and safe guard the rat hearts from oxidative stress coupled with ischemicreperfusion injury [36]. Amla had been proven to be hapatoprotective against a wide variety of liver damaging agents for instance ethanol, paracetamol, heavy metals, carbon tetrachloride, hexachlorocyclohexane and antitubercular drugs. Regular intake of Amla is useful in mitigation of hyperlipidemia, hepatocytic carcinoma, metabolic disorders and hepatotoxicity consequential to iron excess. The hepatoprotective actions of Amla are mediated by its free radical capturing antioxidants, anti-inflammatory actions, regulation of the xenobiotic detoxification and lipid metabolism [37]. Emblica officinalis have been evaluated as phytochemical qualitatively (Table 1) quantitatively (Table 2) and ROS (Table 3).

\subsection{Rosa damascena}

In Iran Rosa damascena mill is locally recognized as Gole Mohammadi. Rosaceae family comprises of 200 species and Rosa damascena is one of the most pharmacologically useful species of Rosaceae family. Rosa damascena is an decorative plant and beside its freshening effects, many pharmacological effects including anti-HIV antibacterial, antitussive, antioxidant, hypnotic and antidiabetic effects have been reported for this plant [38]. $\mathrm{Ng}$ have illustrated that the medicinal functions of rosaceae were due to possession of phenolic compounds [39]. Phenolics hold plenty of pharmacological behaviors, such as anticancer, anti-inflammatory, antioxidants and antidepressant. Different products of Rosa damascena all over the world includes rose oil, rose water, dried flowers and products comprising of ethanolic, hydrosol, chloroformic and aqueous extracts of flowers [40]. Boskabady have narrated that its foremost products are essential oil and rose water. Its ethanolic and aqueous extracts have been scrutinized for analgesic activity, hypnotic activity, potentiation of heart rate and contractility, antitussive, antioxidant activity, anti inflammatory and anti-diabetic activity effects. Its essential oils exhibit bronchodilatory, anticonvulsant and antioxidant action [41]. Shohayeb had proved that aqueous and ethanolic extracts of petals and rose oil demonstrated wide spectrum antibecterial action which was more detrimental towards gram-positive bacteria than gram-negative bacteria [42]. While antifungal activity of rose oil and extracts were also examined against mold and yeast with diameter of zones of inhibition ranged between 10.5 to $17.5 \mathrm{~mm}$ produced by disc diffusion assay.

Hajhashemi have stated that Rosa damascene encloses numerous constituents such as glycosides, anthocyanins, terpenes and flavonoids [43]. The pharmacological effects of Rosa damascena are extensive. Most of the central nervous system (CNS) effects are hypnotic anticonvulsant and analgesic. The antidiabetic, laxative, antimicrobial, antioxidant, anti-inflammatory and cardiovascular strengthening are further sound effects of this plant. Anti-diabetic effects of this plant may

be facilitated by inhibition of $\alpha$-glucosidase that decreased carbohydrate assimilation from the small intestine 26]. Ulusoy had accounted antibacterial action of principle components of rose oil which was probababaly mediated by high phenylethyl alcohol content [44]. In addition, Rosa damascena extract was comprised of vitamin $C$ which has anti-inflammatory and antioxidant effects. Mereover, its conventional actions are comprised of cure of chest and abdominal ache, moderate laxative, cardiotonic, diminution of inflammation, cure of digestive and menstrual bleeding troubles. Rose oil is helpful in alleviation of depression, tension nervous and stress. Rose oil also facilitate the wound renovate, diminution of thirst, heal of chronic cough and health of skin [41]. Rosa damascena have been reviewed as phytochemical qualitatively (Table 1), quantitatively (Table 2) and ROS (Table 3).

\subsection{Santalum album}

Santalum album is indigenous to South India mainly Coorg, Chennai and Mysore. Santalum album belongs to family Santalaceae. Arabic name of this herb is Khushb Sandal and its Urdu name is Sandal Safaid or Chandan Safaid. Sandalwood oil is used primarily as coolant, sedative, astringent, disinfectant in bronchial and genitourinary tracts expectorant, timulant and diuretic. Sandalwood oil masks the odour of sweat so widely used in cologne manufacturing industry [45]. Burdock and Carabin, have reported that in human occasional events of allergic reactions are reported in the literature due to sandalwood oil [46]. Despite of limited knowledge of toxicity studies of sandalwood oil, it is extensively used oral for its pharmacological actions.

Sindhu have stated that Santalum album bark have potentials to inhibit insect growth [45]. Sandalwood oil and aqueous extract of bark powder dried by air $(25-1000 \mu \mathrm{g} / \mathrm{mL}$ in phosphate buffer) had presented significant antimicrobial actions against Staphylococcus aureus and other virulent microbial species. Antiviral activity of sandalwood oil has also been evidenced as antiviral agent against Herpes Simplex Virus. Sandalwood oil has also shown significant antioxidant activity. Oil of Santalum album is used as anti-septic, astringent and anti-bacterial while its wood is used as anti-pyretic, astringent, anti-nauseant, antiinflammatory, blood purifier, cardiotonic, carminative, expectorant laxative, sedative, disinfectant, diuretic and to produce cooling effect. Santalum album have been studied as phytochemical qualitatively (Table 1), quantitatively (Table 2) and ROS (Table 3 ).

\subsection{Valeriana officinalis}

Dried roots of the Valeriana officinalis had been used as herbal medicine since the time of ancient Greece and Rome. Valeriana officinalis belongs to family valerianaceae. The plants of valerianaceae family are widespread. Its common name is Indian valerian or Valerian. Geographically Valeriana officinalis is dispersed in regions of Western Himalayas, Kashmir Afghanistan and Pakistan. Its pharmacological actions were defined as anti-anxiety, sedative and as a cure for insomnia [19]. 
Circosta had analyzed that the extract of root and rhizomes of Valeriana officinalis contains $0.2-2.8 \%$ of sesquiterpenes of volatile essential oil which mainly contains valerenic acid, isovaleric, valeric, valerenal, valeranone and other terpenes [47]. Patocka and Jakl, had described that its root extract was comprised of alkaloids $0.01-0.05 \%$ $\mathrm{w} / \mathrm{v}$, volatile essential oil $0.2-02.8 \%$ and iridoid valepotriates $0.5 \%$ $-2.0 \%$ [19]. Major alkaloids of Valeriana officinalisare valeranine, alpha-methyl pyrylketone, chatinine and skyanthine. On the other hand, Murti had found that its extracts holded $0.5 \%-2.0 \%$ of Iridoid valepotriates and it also contained triterpenes, lignans and flavonoids (Table 2) [20]. Dugaheh had also analyzed Valeriana officinalis and reported that 0.020 to $0.075 \%$ of valeric acid was found in dried extract of Valeriana officinalis [48].

Wang have reported thatValeriana officinalis consist of essential oils which are responsible for its wide spectrum antibacterial action [24]. The essential oils also presented reasonable antifungal actions against Candida albicans growth. Patocka and Jakl, reported that Valeriana officinalisis commonly known for its beneficial effects as an anti-anxiety and sedative drug in traditional system of medication [19]. Its dried root is utilized mainly for its hypnotic and sedative actions in patients with insomnia and anxiety when administered for long periods. Valeriana officinalis extracts interrelate with the GABA, adenosine, barbiturate and benzodiazepine receptors in order to produce hypnotic effects. Valerian is a harmless herbal way for the management of gentle insomnia. Other folk uses of Valerian are found as treatment of gastrointestinal pain and spastic colitis. Valerian also exhibits coronary dilating and antiarrthymic effects. Murti have narrated that antiarrhythmic and coronary artery dilatating effects of valerian extract in mice, rabbits and cat might be due to valepotriates [20]. Valepotriates protects the emergence of acute coronary insufficiency via a short-term raise of blood flow to coronary artery and exert reasonable positive ionotropic and negative chronotropic effects. In addition to these, Valeriana officinalis conventionally are used in the cure of gastrointestinal spasms. As Valerian tastes bitter and bitters have traditionally been used to improve digestion and appetite. Valeriana officinalis have been evaluated as phytochemical qualitatively (Table 1), quantitatively (Table 2) and ROS (Table 3).

\section{CONCLUSION}

Herbal natural medicinal plants are being used tremendously throughout the entire world since they are on the lower price, more efficacy and minor side effects. Plants consist of phytochemical constituents as flavonoids and phenols etc that fulfill the human needs. Therefore, natural plants are being used tremendously by peoples than the allopathic medicines because plants having such type of components which act as antioxidant activity and act as an excellent tonic for stomach, liver and heart.

\section{REFERENCES}

[1] Ahmed, S., Anuntiyo, J., Malemud, C.J., Haqqi, T.M. 2005. Biological basis for the use of botanicals in osteoarthritis and rheumatoid arthritis: a review. Evid. Based Complement. Alternat. Med., 2, 301-308.

[2] Elberry, A.A., Harraz, F.M., Ghareib, S.A., Gabr, S.A., Nagy, A.A., AbdelSattar, E. 2011. Methanolic extract of Marrubium vulgare ameliorates hyperglycemia and dyslipidemia in streptozotocin-induced diabetic rats. Int. J. Diabetes Mellit., 11, 1877-1878.

[3] Kumar, S.P., Rahul, B., Sumit, V., Rashmi, A. 2014. Phytochemical Investigation of Ethanolic extract of Piper nigrum, Zingiber officinale and Allium sativum. Int. Res. J. Pharm., 5 (11), 814-816.

[4] Birben, E., Sahiner, U.M., Sackesen, C., Erzurm, S., Kalayci, O. 2012. Oxidative Stress and Antioxidant Defense. World Allergy Organization Journal, 5, 9-19.
[5] Bisht, V. K., Negi, J.S., Bhandari, A.K., Sundriyal, R.C. 2011. Amomum subulatum Roxb: Traditional, phytochemical and biological activities-an overview. Afr. J. Agric. Res., 6, 5386-5390.

[6] Prakash, K.D., Brajesh, K., Arshad, H., Shikhar, V., Mala, M. 2012. Evaluation of antioxidant activity of large cardamom (leaves of Amomum subulatum). Int. J. Drug Dev. Res., 4, 175-179.

[7] Bairwa, G.L., Jasuja, D., Joshi, S.C. 2011. Lipid lowering and antioxidant effects of amomum subulatum seeds (family zingiberaceae) in cholesterol fed rabbits. Archives Phytopathology plant protectection, 44, 1425-1431.

[8] Gupta, M. 2010. Pharmacological properties and traditional therapeutic uses of important indian spices: a review. Int. J. Food Prop., 13, 1092-1116

[9] Tijjani, M.A., Dimari, G.A., Buba, S.W., Khan, I.Z. 2012. In-Vitro antibacterial properties and pre-liminary phtytochemical analysis of Amomum subulatum Roxburg (Large Cardamom). J. Appl. Pharm. Sci., 02, 69-73.

[10] Kumar, U., Kumar, B., Bhandari, A., Kumar, Y. 2010. Phytochemical investigation and comparison of antimicrobial screening of clove and cardamom. Int. J. Pharm. Sci. Res., 1, 138-147.

[11] Raja, A.M., Shailaja, V., Banji, D., Rao, K.N.V., Selvakumar, D. 2014. Evaluation of standardisation parameters, pharmacognostic study, preliminary phytochemical screening and in vitro antidiabetic activity of Emblica officinalis fruits as per WHO guidelines. J. Pharmacogn. Phytochem., 3, 21-28.

[12] Himesh, S., Nanda, S., Ak, S.A., Jitender, M. 2012. Radical scavenging activities and natural indicator activity of aqueous and ethanolic extract of Rosa damascena. Int. J. Pharm. Pharm., 4, 581-586.

[13] Misra, B.B., Dey, S. 2012. Comparative phytochemical analysis and antibacterial efficacy of in vitro and in vivo extracts from East Indian sandalwood tree (Santalum album L.). Lett. Appl. Microbiol., 55, 476-486.

[14] Sharifzadeh, M., Hadjiakhoondi, A., Khanavi, M., Susanabadi, M. 2006. Effects of aqueous, methanolic and chloroform extracts of rhizome and aerial parts of Valeriana officinalis L. on naloxone-induced jumping in morphine-dependent mice. Addict. Biol., 11, 145-151.

[15] Hazra, B., Sarkar, R., Biswas, S., Mandal, N. 2010. Comparative study of the antioxidant and reactive oxygen species scavenging properties in the extracts of the fruits of Terminalia chebula, Terminalia belerica and Emblica officinalis. BMC Complement. Altern. Med., 10, 10-20.

[16] Nampoothiri, S.V., Prathapan, A., Cherian, O.L., Raghu, K.G., Venugopalan, V.V., Sundaresan, A. 2011. In vitro antioxidant and inhibitory potential of Terminalia bellerica and Emblica officinalis fruits against LDL oxidation and key enzymes linked to type 2 diabetes. Food Chem. Toxicol., $49,125-131$

[17] Hameed, E.S.A., Bazaid, S.A., Shohayeb, M.M. 2012. Antioxidant activity, total phenolics and RP-HPLC analysis of defatted fresh Taif rose, Saudi Arabia. British J. Pharmaceut. Res., 2, 129-140.

[18] Baydara, N.G., Baydarb, H. 2013. Phenolic compounds, antiradical activity and antioxidant capacity of oil-bearing rose (Rosa damascena Mill.) extracts. Ind. Crops Prod., 41, 375- 380. 
[19] Patocka J., Jakl, J. 2010. Biomedically relevant chemical constituents of Valeriana officinalis. J. Appl. Biomed., 8, 11-18.

[20] Murti, K., Kaushik, M., Sangwan, Y., Kaushik, A. 2011. Pharmacological properties of Valeriana officinalis- a review. Pharmacologyonline, 3, 641646.

[21] Devi, S.A., Umasankar, M.E., Babu, S. 2012. A comparative study of antioxidant properties in common Indain spices. Int. Res. J. Pharm., 3, 465468.

[22] Souri, E., Amin, G., Farsam, H., Tehrani, M.B. 2008. Screening of antioxidant activity and phenolic content of 24 medicinal plant extracts. Daru J. Pharm. Sci., 16, 83-87.

[23] Jain, S.K., Khurdiya, D.S. 2004. Vitamin C enrichment of fruit juice based ready-to-serve beverages through blending of Indian gooseberry (Emblica officinalis Gaertn) juice. Plant Foods Hum. Nutr., 59, 63-66.

[24] Wang, J., Zhao, J., Liu, H., Zhou, L., Liu, Z., Wang, J., Han, J., Yu, Z., Yang, F. 2010. Chemical analysis and biological activity of the essential oils of two valerianaceous species from China: Nardostachyschinensisand Valeriana officinalis. Molecules, 15, 6411-6422.

[25] Sharma, S., Sharma, J., Kaur, G. 2011. Therapeutic uses of elettaria cardomum. Int. J. Drug Formulation Res., 2, 102-108.

[26] Gholamhoseinian, A., Fallah, H., Sharifi, F., Mirtajaddini, M. 2008. The inhibitory effect of some Iranian plants extracts on the alpha glucosidase. Iran J. Basic Med. Sci., 11, 1-9.

[27] Khan. K.H. 2009. Roles of Emblica officinalisin medicine - a review. Bot. Res. Int., 2, 218-228.

[28] Dnyaneshwar, W., Preeti, C., Kalpana, J., Bhushan, P. 2006. Development and application of RAPD-SCAR marker for identification of Phyllanthus emblica Linn. Biol Pharm Bull., 29, 2313-2316.

[29] Vijayalakshmi, S., Arunkumar, V., Anju, D., Gunasundari, P., Moorthyand, P., Chandrasekharan, A.K. 2007. Comparative antimicrobial activities of Emblica officinalis and Ocimum sanctum. Anc. Sci. Life., 27, 16.

[30] Mayachiew, P., Devahastin, S. 2008. Antimicrobial and antioxidant activities of Indian gooseberry and galangal extracts. Food Sci. Technol., 41, 1153-1159.

[31] Goel, R.K., Bhattacharya, S.K. 1991. Gastroduodenal mucosal defense and mucosal protective agents. Indian J. Exp. Biol., 29, 701-714.

[32] Sairam, K., Rao, C.V., Babu, M.D., Kumar, K.V., Agrawal, V.K., Goel, R.K. 2002. Antiulcerogenic effect of methanolic extract of Emblica officinalis: an experimental study. J. Ethnopharmacol., 82, 1-9.

[33] Ghosal, S., Tripathi, V.K., Chauhan, S. 1996. Active constituents of Emblica officinalis: Part1-the chemistry and antioxidant effects of two hydrolysable tannins, emblicanin A and B. Indian J. Chem., 35, 941-948.
[34] Aguwa, C.N., Nwako, S. 1988. Preliminary studies on the root extracts of Nauclea latifoliaSmith, for anti-ulcer properties. Niger. J. Pharm. Sci. 4, 16-23.

[35] Perianayagam, J.B., Narayanan, S., Gnanasekar, G., Pandurangan, A., Raja, S., Rajagopal, K., Rajesh, R., Vijayarajkumar, P., Vijayakumar, S.G. 2005. Evaluation of antidiarrheal potential of Emblica officinalis. Pharm. Biol., 43, 373-377.

[36] Rajak, S., Banerjee, S.K., Sood, S., Dinda, A.K., Gupta, Y.K., Gupta, S.K., Maulik, S.K. 2004. Emblica officinalis causes myocardial adaptation and protects against oxidative stress in ischemic-reperfusion injury in rats Phytother. Res., 18, 54-60.

[37] Thilakchand, K.R., Mathai, R.T., Simon, P., Ravi, R.T., Rao M.P., Baliga, M.S. 2013. Hepatoprotective properties of the Indian gooseberry (Emblica officinalis Gaertn): a review. Food Funct., 4, 1431-1441.

[38] Hongratanaworakit, T. 2009. Relaxing effect of rose oil on humans. Nat. Prod. Commun., 4, 291-296.

[39] Ng, T.B., Liu, F., Wang, Z.T. 2000. Antioxidative activity of natural products from plants. Life Sci., 66, 709-723.

[40] Kurkcuoglu, M., Baser, K.H.C. 2003. Studies on Turkish rose concrete, absolute and hydrosol. Chem. Nat. Compounds., 39, 375-379.

[41] Boskabady M.H., Shafei, M.N., Saberi, Z., Amini, S. 2011 Pharmacological effects of Rosa damascena. Iran. J. Basic Med. Sci., 14, 295307.

[42] Shohayeb, M., Sayed, S.A., Hameed, A., Bazaid, S., Maghrabi, I. 2014. Antibacterial and antifungal activity of Rosa damascene Mill. essential oil, different extracts of rose petals. Global J. Pharmacol., 8, 01-07.

[43] Hajhashemi, V., Ghannadi, A., Hajiloo, M. 2011. Analgesic and antiinflammatory effects of Rosa damascena hydroalcoholic extract and its essential oil in animal models. Iran J. Pharm. Res., 9, 163-168.

[44] Ulusoy, S., Tinaz, G.B., Canbay, S. 2009. Tocopherol, carotene, phenolic contents and antibacterial properties of rose essential oil, hydrosol and absolute. Curr Microbiol., 59, 554-558.

[45] Sindhu, R., Upma, K., Kumar, A., Arora, S. 2010. Santalum album linn: a review on morphology,phytochemistry and pharmacological aspects. Int. J. Pharm. Tech. Res., 2, 914-919.

[46] Burdock, G.A., Carabin, I.G. 2008. Safety assessment of sandalwood oil (Santalum album L.). Food Chem. Toxicol., 46, 421-32.

[47] Circosta, C., Pasquale, R.D., Samperi, S., Pino, A., Occhiuto, F. 2007. Biological and analytical characterization of two extracts from Valeriana officinalis. J. Ethnopharmacol., 112, 361-367.

[48] Dugaheh, M.A., Meisami, F., Torabian, Z., Sharififar, F. 2013. Antioxidant effect and study of bioactive components of Valeriana sisymbriifolia and Nardostachys jatamansii in comparison to Valeriana officinalis. Pak. J. Pharm. Sci., 26, 53-58. 